DOI https://doi.org/10.30525/978-9934-26-006-3-11

\title{
ВИКОРИСТАННЯ МАКРОФІТІВ В БІОТЕХНОЛОГІЇ ДООЧИСТКИ ПОВЕРХНЕВИХ ТА СТІЧНИХ ВОД
}

\author{
Крот Ю. Г.
}

кандидат біологічних наук, старший науковий співробітник, в. о. завідувача відділу екологічної фізіологї гідробіонтів та біотехнологіi

Інститут гідробіології Наџіональної академії наук Украӥни

Гончарова М. Т.

кандидат біологічних наук,

старший науковий співробітник відділу екологічної фізіологї

гідробіонтів та біотехнології

Інститут гідробіології Національної академії наук України

\section{Коновець І. М.}

кандидат біологічних наук, старший науковий співробітник, завідувач лабораторією біологічно активних сполук

Інститут гідробіології Національної академії наук Украӥни м. Київ, Україна

Вищі водяні рослини відіграють виключну роль у процесах самоочищення водойм завдяки своїй здатності до накопичення, утилізації та трансформації багатьох забруднюючих речовин. Макрофіти є одною 3 ключових біотичних ланок у формуванні якості води: вони збагачують в процесі своєї життєдіяльності воду киснем, сприяють осіданню завислих речовин, поглинають біогенні елементи та деякі органічні речовини, здатні до накопичення та детоксикації деяких металів та токсичних речовин в концентраціях, що перевищують фонові значення [5]. Повітряно-водні рослини прибережних ділянок $\epsilon$ першим бар'єром для забрудненого стоку 3 водозбірної території. В їх заростях осідає значна кількість мінеральних та органічних завислих речовин. Ці властивості дозволили успішно використовувати деякі 3 найбільш потенційно придатних видів водних рослин для доочистки виробничих та господарсько-побутових стічних вод [4]. Природні i штучні «біоплато» 3 використанням макрофітів використовують як водоохоронні споруди для очистки води від забруднюючих речовин [1-2]. В природних умовах при їх функціонуванні у водоймах i водотоках утворюються специфічні зони, в яких зосереджуються різноманітні види рослин та тварин і більш активно 
протікають процеси відновлення якості водного середовища. Фітоценози, бактеріальні угруповання, водяні тварини виконують в них роль середовищеутворюючого чинника i сприяють процесам утилізації, трансформації i транспорту біогенних елементів та забруднюючих речовин [4].

Метою нашого дослідження була оцінка функціонування плаваючого «біоплато» 3 повітряно-водними рослинами - очеретом звичайним Phragmites australis для доочистки стічних вод.

Матеріал і методика досліджень. Для проведення експериментальних досліджень по доочистці і кондиціюванню стічних вод створено експериментальний гідрофітний модуль (ЕГМ) з біоценозом, до складу якого входять вищі водні рослини (едифікатори), мікроорганізми та супутні гідробіонти. Видом-едифікотором слугував Phragmites australis.

В ЕГМ з оборотною системою водопостачання стічна вода з ємностінакопичувача подається у контейнер 3 повітряно-водними рослинами, проходить крізь їх придаткову кореневу систему і через сітчасте дно повертається у ємність-накопичувач. Після чого цикл повторюється. Об’єм ЕГМ становить 300 дм $^{3}$ (об'єм контейнера з рослинами 47 дм $^{3}$ ), швидкість протоку 60 дм³/год. Гідробіоценоз ЕГМ проходив адаптацію до підвищеного вмісту органічних речовин протягом 10 діб. Гідрохімічний аналіз виконували стандартними методами [3].

Результати досліджень. 3 метою визначення впливу трансформації забруднюючих речовин в експериментальному гідрофітному модулі (ЕГМ) на процес кондиціювання стічних вод досліджено зміну гідрохімічних показників на початку експерименту і через 24 години експозиції в стаціонарних умовах (без протоку середовища). В якості контролю використовували модуль із забрудненим вихідним середовищем без розміщення у ньому водних рослин (табл. 1).

Таблиця 1

Гідрохімічні показники модельного середовища в експериментальному гідрофітному модулі без протоку, експозиція 24 години

\begin{tabular}{|l|c|c|c|c|c|c|}
\hline \multicolumn{1}{|c|}{$\begin{array}{c}\text { Гідрохімічні } \\
\text { показники }\end{array}$} & $\mathbf{N H}_{\mathbf{4}}{ }^{+}$ & $\mathbf{N O}_{\mathbf{2}}^{-}$ & $\mathbf{N O}_{\mathbf{3}}^{-}$ & $\mathbf{P O}_{\mathbf{4}}{ }^{--}$ & $\mathbf{X C K}$ & $\mathbf{p H}$ \\
\hline Вихідне середовище & 1,00 & 0,01 & 38,20 & 11,00 & 81,40 & 8,00 \\
\hline $\begin{array}{l}\text { ЕГМ через 24 год } \\
\text { експозиції }\end{array}$ & 0,94 & 0,22 & 37,25 & 12,22 & 81,40 & 7,83 \\
\hline $\begin{array}{l}\text { Контроль (без } \\
\text { рослин) через 24 год } \\
\text { експозиції }\end{array}$ & 0,99 & 0,03 & 38,10 & 10,95 & 81,40 & 8,00 \\
\hline
\end{tabular}


Перебування забрудненої біогенними речовинами модельної вихідної води протягом 24 годин в ЕГМ призвело до незначного зниження концентрації $\mathrm{NH}_{4}{ }^{+}, \mathrm{NO}_{3}{ }^{-}$та достовірного підвищення, майже на порядок $\mathrm{NO}_{2}^{-}$. При цьому у контрольній ємності (без рослин) також відмічено тенденцію до підвищення $\mathrm{NO}_{2}^{-}$.

Відмічена закономірність зміни неорганічних сполук азоту в обох системах може свідчити про початок проходження в них процесів нітрифікації, найбільш ефективно в ЕГМ. Однак, процеси мінералізації органічних речовин ще не носять інтенсивний характер. Про це свідчить високий незмінний рівень показника хімічного споживання кисню (ХСК), незначні коливання фосфору фосфатів та величини $\mathrm{pH}$, при знижені останньої в ЕГМ в кислу сторону.

Отже, для більш ефективного проходження процесів мінералізації і нітрифікації в ЕГМ (без протоку) необхідно враховувати період адаптації гідробіоценозу до складу і властивостей стічної води, а також необхідної в ній кількості біогенних поживних речовин.

Результати роботи ЕГМ 3 оборотною системою водопостачання показали, що ефективність очистки модельного середовища, забрудненого органічними речовинами, в умовах оборотного водопостачання (сім діб експозиції) становила: за показниками фосфор фосфатів - 48 \%, хімічне споживання кисню - 68 \% (табл. 2).

При цьому динаміка вмісту неорганічних сполук азоту в ЕГМ за 7 діб експозиції мала деякі особливості. Так, після незначного зниження $\mathrm{NH}_{4}^{+}$(друга доба) відмічено його підвищення і подальша стабілізація на рівні 1,5 мг/дм ${ }^{3}$. При цьому спостерігалось зниження концентрації $\mathrm{NO}_{2}{ }^{-}$та підвищення $\mathrm{NO}_{3}{ }^{-} 3$ подальшими незначними коливаннями останнього у межах $10 \%$. Величина $\mathrm{pH}$ зміщувалась у лужну сторону і знаходилась на рівні 8,0.

Таблиця 2

Ефективність очистки забрудненої води (модельне середовище) в експериментальному гідрофітному модулі

\begin{tabular}{|c|c|c|c|c|c|c|}
\hline \multirow{2}{*}{ Назва показника } & \multicolumn{6}{|c|}{ Доба } \\
\hline & $\mathbf{0}$ & 1 & 2 & 3 & 6 & 7 \\
\hline Азот амонійний, мг/дм ${ }^{3}$ & 1,28 & 1,24 & 1,20 & 1,43 & 1,48 & 1,57 \\
\hline Азот нітритів, мг/дм ${ }^{3}$ & 0,025 & 0,025 & 0,011 & 0,007 & $\leq 0,01$ & $\leq 0,01$ \\
\hline Азот нітратів, мг/дм ${ }^{3}$ & 39,5 & 43,3 & 39,8 & 41,8 & 41,0 & 38,9 \\
\hline Фосфор фосфатів, мг/дм ${ }^{3}$ & 13,9 & 9,9 & 12,1 & 11,6 & 8,9 & 7,2 \\
\hline $\begin{array}{c}\text { Хімічне споживання кисню, } \\
\text { мгО/дм }{ }^{3}\end{array}$ & 81,4 & 59,2 & 33,5 & 44,2 & 33,0 & 26,4 \\
\hline Величина $\mathrm{pH}$, од. $\mathrm{pH}$ & 7,31 & 8,10 & 7,97 & 8,05 & 8,09 & 8,07 \\
\hline
\end{tabular}


Враховуючи те, що процеси амоніфікації проходять одночасно 3 розкладанням органічних азотовмісних сполук i зумовлюються виділенням йонів $\mathrm{NH}_{4}{ }^{+}$чи вільного аміаку, а процеси нітрифікації найбільш активно протікають після виділення зі стічної води основної маси органічних сполук, оскільки їх присутність знижує активність нітрифікаторів, попередня адаптація гідробіоценозу ЕГМ до підвищеної кількості органічних речовин, вже на початку експерименту сприяла проходженню процесів амоніфікації органічної речовини та прискорення нітрифікації. Необхідно відмітити, що у період досліджень (січень - березень) ЕГМ не характеризувався максимальним функціональним станом, оскільки період його активної вегетації спостерігається у літні місяці.

Таким чином, забруднена органічними речовинами вода після проходження ЕГМ за основними показниками відповідала вимогам, які висуваються до ії якості для повторного застосування. Ефективність очищення за показником хімічного споживання кисню становила $68 \%$, за фосфором фосфатів - 48 \%. Провідними чинниками, що впливають на очисну здатність ЕГМ, можна вважати швидкість протоку, об'єм та площу кореневої системи рослин. Для покращення перебігу біохімічних процесів необхідно забезпечити достатню кількість розчиненого кисню, нестача якого може пригнічувати як процеси нітрифікації, так і негативно впливати на життєдіяльність водних організмів.

\section{Література:}

1. Гвоздяк П.І. За принципом біоконвеєра. Вісник НАН України. 2003. № 3. C. 29-36.

2. Крот Ю.Г. Высшие растения в биотехнологиях очистки поверхностных и сточных вод. Гидробиол. журн. 2006. 42, № 1. C. 47-61.

3. Методи гідроекологічних досліджень поверхневих вод (за ред. В.Д. Романенка). К. : Логос. 2006. 408 с.

4. Природні і штучні біоплато. Фундаментальні та практичні аспекти. Романенко В.Д., Крот Ю.Г., Киризій Т.Я. К. : Наук. думка. 2012 p. 112 c.

5. Тимофеева С.С. Биотехнология обезвреживания сточных вод. Хим. и технол. воды. 1995. № 5. С. 525-532. 